\title{
Going Regional: The Evolution of an Organizing Strategy in Detroit
}

\author{
Lara Rusch* \\ University of Michigan-Dearborn
}

\begin{abstract}
In contexts of entrenched metropolitan inequality and limited local resources, organizers and community activists often feel a sense of urgency to target higher levels of government. This paper offers one such case from Detroit, of local organizing projects that "scaled up" in the mid-1990s to pursue a regional equity agenda. Drawing on participant observation, archival data, and interviews, the paper examines the process of unification and identifies key shifts in purpose, relational base, approach to leadership, and strategy for empowerment. While scaling up enabled members to engage in more sophisticated actions and influence higher levels of policy making, it also challenged the organization to maintain its member base. This research suggests that the process of scaling up poses tradeoffs for grassroots organizations, between responsiveness to existing members and building a regionally representative organization, capable of transcending divisions of the political environment.
\end{abstract}

\section{INTRODUCTION}

Numerous scholars of congregation-based community organizing (CBCO) have argued that an eventual scaling up of local efforts is necessary to challenge the regional, state, and national origins of metropolitan inequity (DeFilippis et al. 2010; Scully 2008; Wilson 1999; Wood 2007). From Alinsky's Chicago to present-day Camden, observers have critiqued the limitations of parochial organizing and emphasized the need for broader, more diverse coalitions (Gillette 2005; Santow 2007). By "scaling up," I refer to a process of coordination or unification among locally rooted organizations for increased capacity, reach, and impact at higher levels of policy making. ${ }^{1}$

Existing research outlines the benefits of scaling up, both for the strength of organizations and for policy impact. At the regional level, scaling up is a political strategy for achieving policy coordination as a solution to urban crises, to overcome the isolation of the urban poor and protect inner suburbs from disinvestment and decline (Dreier et al. 2004; Orfield 1997, p. 50; Rusk 1993, 1999). It expands the scope of conflict to win the weak new allies and put their issues on local and state policy agendas (Schattschneider 1975). In the 1990s, the Gamaliel Foundation's faith-based network adopted regional

*Correspondence should be addressed to Lara Rusch, PhD, University of Michigan-Dearborn, 2154 Social Sciences Building, 4901 Evergreen, Dearborn, MI 48128; lrusch@umd.umich.edu

City E Community 11:1 March 2012

doi: 10.1111/j.1540-6040.2011.01393.x

(C) 2012 American Sociological Association, 1430 K Street NW, Washington, DC 20005 
equity organizing to expand its reach through regional coalitions (Kleidman 2004; Pastor et al. 2009, pp. 103-104; Swarts 2008). Regional equity offers a unifying theory that neighborhood organizing lacks (Heathcott 2005, p. 290). It offers a strategy of building collective power through coalitions that link the experiences of congregations across municipal and racial boundaries (Dreier et al. 2004). Beyond the regional level, targeting higher levels of government is a strategic decision as public coffers continue to shrink locally (Swarts 2007, p. 134). Increasingly, governance is rescaling from the city to the metropolitan level (Brenner 2003; Katz 2010). And organizing at a regional level or higher creates opportunities for developing leadership, attracting resources, and shaping policy that can "enhance the capacity for local work" (Warren 2001, p. 95).

The question of how to move beyond a local constituency is not new to organizing (DeFilippis et al. 2010, p. 51). ${ }^{2}$ Robert Kleidman (2004) identifies a "dilemma of scale" for organizers: how to influence higher-level targets "while retaining local organizing's participatory democracy" (p. 404). Existing research offers examples of organizations that have scaled up successfully while maintaining local engagement. ${ }^{3}$ CBCO federations tend to privilege local autonomy, but some networks have overcome this limitation by effectively linking their local affiliates, such as the Industrial Areas Foundation (IAF) in Texas and Arizona, or People Improving Communities Through Organizing (PICO) in California. [See Appendix A for a complete list of abbreviations.] ${ }^{4}$ This coordination has provided the contacts, expertise, and staff support necessary for local groups to assert influence in state politics (Warren 2001). In his research on PICO network, Richard Wood (2007) describes the deliberative process that led PICO's California affiliates to add national campaigns to their state and local organizing (also see Ganz 2000). This "broadly consultative process" engaged leaders on whether and how to shift their energies, resources, and political capital (p. 176).

Alongside the benefits of scaling up, scholars describe challenges and tensions for participants. Whereas many local leaders feel a sense of urgency to expand, others question how state or national goals reflect their self-interests (Warren 2001, p. 95). The engagement of local people through a national "mobilization infrastructure" requires more monetary resources, already scarce for CBCOs. And skill in local organizing does not necessarily translate into policy expertise necessary for national advocacy (Miller 2008; Swarts 2007, p. 137). The prospect of scaling up also raises tensions between prioritizing the value of deliberation versus leadership-driven change, what Wood (2007) calls "entrepreneurial authority," within democratic organizations (p. 187). For example, PICO's leaders have emphasized, "we are proposing a strategy-we don't impose our will on any project" (p. 179).

Existing research also suggests that the arrangement of social capital within community organizations affects their capacity to scale up. Since the remaking of the IAF in the 1970s, CBCO has sought to develop both bonding and bridging social capital, applying relational practices and cultural sensitivity to the power-based model (Cortes 1993; DeFilippis et al. 2010; Rogers 1990; Warren 2001). The resulting model develops closeknit relationships within congregations. But it also seeks bridging ties, linking more diverse institutions with common interests. Research suggests a fundamental tension in this balance and that homogeneous organizations are more successful at mobilization (Putnam 2000, 2007). Kristina Smock (2004) has found that organizing models tend to emphasize either bonding or bridging. "Community building" and "women-centered" models of organizing invest the most energy in mutual support but develop less capacity 
to expand their networks. In contrast, institution-based organizing is most successful at increasing "community ability to solve problems through public action," but offers a limited basis for mutual support (p. 95). Scaling up may reinforce CBCO's tendency toward weaker ties and lower responsiveness to members' immediate concerns.

Although existing research has outlined key benefits and costs of scaling up local organizing, there is a need for a better understanding of transitions in organizational structure as a core element of organizing praxis. Scaling up is challenging because it requires not just a replication of the same organization on a larger stage, but a transformation of organizational form through a democratic process. A shift in purpose and scale requires an expanding set of relationships and adaptations in the engagement of existing members. Community organizing helps members to develop a shared public voice and to be heard by public officials. But expanding in scale challenges groups to maintain their identity and members' sense of ownership.

\section{RESEARCH METHODS}

This case study follows the evolution of Metropolitan Organizing Strategy Enabling Strength (MOSES), a community organizing project in Detroit from 1989 to 2006. Case study methodology brings the researcher into the context being analyzed, to "illuminate a decision or set of decisions" (Schramm 1971, quoted in Yin, p. 12). The decisions of interest in this case are the choices by organizers and leaders to scale up their local districts for more power in the region and the state. To achieve contextual understanding and to check sources, this chronology of organizational change incorporates data collected with several methods, including archival research, participant observation, and interviews. ${ }^{5}$ From 2003 to 2006, I participated in staff, leadership, training, and task force meetings, as well as in public action. Data were also collected from 49 semistructured interviews recorded in 2005 and 2006 with organizers, clergy, and active lay leaders. ${ }^{6}$ Before beginning interviews I conducted two focus groups in June 2005, one with a group of suburban clergy north of the city, and one with African American clergy in Southwest Detroit. Based on the focus groups and participation, I mostly limited interviews to city congregations to focus on organizing challenges in the context of depopulation and disinvestment. ${ }^{7}$

The paper draws on time-ordered matrices for synthesis and analysis of multiple forms of data across 17 years of MOSES's history (Miles and Huberman 1994). By tracking key changes in organizational structure and key events over time, I categorized key stages of development and linked the changes in the organization's structure to its goals, practices, and democratic values.

\section{PHASES IN ORGANIZATIONAL DEVELOPMENT}

The section below provides a history of the development of MOSES, from its precursors in the late 1980s through the decision to unify in 2006. This history focuses on the evolution of strategy determined by organizers and leaders in response to numerous factors: their early actions, successes, and obstacles; expanding contacts; the process of learning about regional equity; and interpretations of the political context. From this chronology four phases of organizational structure become apparent: (1) independent, loosely connected districts linking proximate congregations; (2) a period of discussion and transition 


\begin{tabular}{|l|l|l|l|l|}
\hline Years & 1989-1995 & 1996-1998 & 1999-2005 & 2006-present \\
\hline $\begin{array}{l}\text { Phases in } \\
\text { Structure }\end{array}$ & $\begin{array}{l}\text { District-based: } \\
\text { geographical districts } \\
\text { maintain their own } \\
\text { boards, issues, sub- } \\
\text { committees, and } \\
\text { actions }\end{array}$ & $\begin{array}{l}\text { Transition into a } \\
\text { city-wide structure, } \\
\text { linking districts }\end{array}$ & $\begin{array}{l}\text { Representative } \\
\text { city-wide } \\
\text { organization, } \\
\text { growing regionally }\end{array}$ & $\begin{array}{l}\text { Unified regional } \\
\text { organization; } \\
\text { districts dissolved }\end{array}$ \\
\end{tabular}

FIG. 1. Timeline of MOSES's organizational history, 1989-2006.

to connect and coordinate districts; (3) the formation of a representative, citywide organization, growing regionally; and (4) a unified regional organization. These phases are represented as a timeline in Figure 1.

\section{THE POLITICAL CONTEXT AND INITIAL ORGANIZING STRATEGY}

In national parlance, "Detroit" conjures a single image of the Big Three automakers, their rise, fall, and rebirth. But for residents of the metropolitan region-Super Bowl ads notwithstanding ${ }^{8}$ — the name signifies different things; its connotation changes with municipal boundaries. In Southeast Michigan the name connotes racial divisions, economic fragmentation, and competition among municipalities, often propagated by political leaders seeking to consolidate support (Farley, Danziger, and Holzer 2000). Suburban derision and Detroiters' defensiveness have both failed to acknowledge how metropolitan inequity stems from political and corporate choices. June Thomas's (1997) research, for example, details the inability of planners to prevent the city's decline in the context of larger forces, including the auto industry's disinvestment, misguided urban renewal projects, and racism, mobilized from the grassroots against integrated development (also see Sugrue 1996).

The region has suffered without an urban regime to garner the private resources and public support necessary for comprehensive revitalization (Orr and Stoker 1994, p. 65; Stone 1989). Before Coleman Young's mayoralty, Detroit lacked an entrepreneurial leader to coordinate private resources necessary for redevelopment (Thomas 1997, p. 124). Even with Young's leadership_and at times because of it-Detroit's urban regime fragmented into several overlapping civic organizations (Orr and Stoker 1994). Regional corporations lacked a material interest in the city beyond charity or public relations, and the automotive industry could not be won back or replaced by downtown redevelopment (Darden et al. 1987). Detroit also lacks any regional authority with teeth for coordinating transit or land-use, ${ }^{9}$ and with electoral coalitions mapped onto segregated municipalities, the political leadership of city and suburbs only reinforced existing divisions. By the late 1980 s political transformation seemed unlikely, even impossible, as Detroit's economic, physical, and social infrastructure deteriorated.

It is within this context that the history of MOSES begins, when a diverse group of clergy began to consider how they could collaborate and create a "shared view of the future of the city" that eluded elites (Orr and Stoker 1994, p. 67). In 1989, a dozen diverse clergy united to address the crises of social dislocation and poverty in their neighborhoods, forming the West Detroit Interfaith Community Organization (WDIFCO). ${ }^{10}$ It was followed by the Jeremiah Project in 1993, which linked Latino parishes and other diverse congregations in Southwest Detroit. ${ }^{11}$ 
Interested in the power-based model of organizing, the two nascent groups decided to join the Gamaliel Foundation for training and support. ${ }^{12}$ Gamaliel uses a congregationbased strategy, drawing on the organizational and cultural resources of congregations for political action. Gamaliel trains organizers to develop one-on-one relationships with clergy and lay people, to understand their concerns and to build "core teams" within congregations who link the congregation to the larger network. In this model, active laity become "leaders" who engage their peers to investigate local policy and commit to direct action. Organizers encourage an awareness of self-interest and help individuals understand their community challenges in a context of systemic inequities.

Gamaliel's approach reflected an interpretation of neighborhood decline as a loss of community and argued that the rebuilding of community requires both "in-reach"strengthening ties within congregations-and public pressure. ${ }^{13}$ This approach resonated with the clergy in WDIFCO and Jeremiah. A member priest said, "One of the things we learned from the Gamaliel Foundation is the church across the country is suffering from the deterioration of community.... We have to strengthen the church before we can address social needs" (Ludtke 1994). According to this philosophy, clergy and lay people need intentional training to build both healthy congregations and an actionable community, an organized network of local people to bring their tenets of faith to the public sphere and pursue tangible goals for social justice.

\section{REGIONALISM AND THE CREATION OF MOSES}

True to this philosophy, in the early 1990s, WDIFCO and Jeremiah organized "inreach" campaigns within congregations and around neighborhood concerns. They soon achieved visible successes: removing drug paraphernalia in party stores, rehabbing homes, and pressuring the city to tear down abandoned housing and fund parks and recreation (O'Brien 2006). Congregations also created neighborhood "Safe Zones" in which participants surveyed their neighbors about safety concerns in door-to-door "porch patrols" around the area of a church or school (Amick 1996a; Vatcher 1997). ${ }^{14}$ Members developed relationships with law enforcement and met with agencies responsible for public health, public works, street lighting and safety, and businesses (Delaney 1996; Selwa 2002). By the mid-1990s, Safe Zones resulted in dozens of victories: drug houses busted, dump sites cleaned, and dangerous buildings demolished. The city eliminated an area of prostitution on school grounds and reopened a local park. ${ }^{15}$ The districts pressured officials to raze abandoned housing, commit police to work with residents, and redevelop targeted blight (Askari 1994; Hopkins 1994). Jeremiah members successfully lobbied the federal government to build a sound barrier along Interstate $75 .^{16}$

As the victories grew, organizers began considering how to connect their efforts across the city (Amick 1996a). Their interest dovetailed with Gamaliel's consultation with regionalist scholars: presentations by Myron Orfield, David Rusk, and John Powell encouraged the senior staff to adopt regional equity organizing as a guiding strategy. Regional maps and analyses made apparent the dynamics of population movements, poverty, segregation, and taxes, and showed how these processes affect neighborhoods (Orfield and Luce 2003). The research resonated with Detroit activists, providing systemic explanations for what their communities were experiencing and suggesting a strategy that fit their ecumenical values. Organizers were also influenced by 
other Gamaliel affiliates that were "coming to the same conclusion" about regionalism, in Indiana, Chicago, St. Louis, and Cleveland. ${ }^{17}$

After WDIFCO leaders attended a retreat with presentations by Orfield and Rusk, they reflected on their experience with affordable housing development. The district had received a HUD (U.S. Department of Housing and Urban Development) Hope III Implementation Grant and rehabbed houses with that funding over five years. The usual approach had been to target a single dilapidated house, but "six months later, there were three more abandoned houses on that block" (Liske 2005). They became concerned that their efforts were ultimately concentrating poverty, limiting families' chances for long-term success. "The leaders said, we've got to create an organization that's metrowide and working on some of these issues" (Liske 2005). As political organizing became more central to their mission, WDIFCO separated the housing component and renamed the political organizing project RUTH. ${ }^{18}$

Persuaded about the limitations of localism, in 1994 the WDIFCO leadership ratified a "Metro Organizing Strategy" (MOS) to support creating other city districts, with the intention to build a federation in $1996 .{ }^{19}$ Seeking to maintain internal accountability and anticipating needless competition, the districts rejected the goal of a local federation in favor of one metrowide organization. Liske wrote, "Assuming we can create strong congregational and regional structures ... this is the best option for a strong future." 20

Organizers knew that this was not a given; creating strong congregational teams proved an ongoing challenge. In a memo to the MOS Steering Committee in August 1995, Liske wrote, "With the exception of the southwest region, none of the regions are anywhere near where we had hoped eight months ago. The southeast region especially is way behind the schedule. It in essence doesn't exist except in a few (but determined) pastors' minds." The Northeast Organization Allied for Hope (NOAH), covering eastern and central Detroit, began meeting as a third district in 1995. The group achieved some small victories such as greater police patrols in Northeast neighborhoods, but they never achieved the grounding of the western districts (Amick 1996b). And other organizing efforts on the lower east side, for a time called ESTHER, never coalesced into a district. ${ }^{21}$ Over a period of at least three years, the districts discussed the creation of a metropolitan organization. Organizer Ponsella Hardaway explained that they wrestled with this transition:

We were just neighborhood organizing and we wanted to hold the mayor accountable for the garbage dumps in our neighborhoods and the blighted housing. [ ... ] You have to constantly talk to people about this sophisticated way of organizing to get them to understand. Oh, this is why our region is in such trouble. (Hardaway 2006).

Jeremiah's board minutes from February 1996 suggest uncertainty among the clergy. They hoped that by combining the districts they would be able to acquire more funding, accomplish more on a larger scale, and maintain Jeremiah's identity. But some asked for examples of how the churches would benefit, and one pastor argued, "we should move slower, or we will not accomplish much with our organizing." 22

A meeting on April 20, 1996, included Myron Orfield to address district leaders on the following questions: "Do we need MOSES? How would our lives be better? Will MOSES help my congregation? What would MOSES look like?"23 In a speech to Jeremiah 
members, Rev. Cain of Waterfall Baptist spoke to uncertainty over the metropolitan strategy.

As we were planning the agenda... the question came up about how we can convince our congregations of the need for a MOSES. Then my thoughts were - how quickly we forget, or how slow we are to remember and understand what Jeremiah has done by itself and what the others have done by themselves. Now, what do you think we could do together? Could we hurt ourselves by being in an organization that covers the counties of Wayne, Oakland, or Monroe? ${ }^{24}$

In an urgent speech to a meeting of the combined districts in June 1996, lay leader Victoria Kovari ${ }^{25}$ advocated for unification, connecting the prophet Jeremiah's call to "return people to the land" to the need for the districts to collectively push for government action on land use.

We need to get the city and county together and stop fighting each other. We need to get them together to support community groups that are doing housing. [...] Nobody else is going to start rebuilding these neighborhoods. [...] So, we the people who are going to make up MOSES [ ... ] we must change the way land is used and abused in this community, across Wayne county, across metropolitan Detroit. We need each other. Jeremiah-I'm telling you-Jeremiah cannot do it by itself. I'm telling you we have tried. We have tried. We can't even get a list of the property the city owns in our neighborhood, let alone change the way they use it. WDIFCO is the same way, NOAH you can't do it by yourself. We have no choice but to get together all of us across the city and say, hey this is the way it's going to be. ${ }^{26}$

Kovari and other leaders interpreted their inability to challenge the dynamics of disinvestment as proof they needed a larger organization. Despite uncertainty on what joining forces would mean for congregations, members moved toward unification. In September 1998, the organizations held a "Visioning Conference" to review and agree upon a mission and basic goals, analyze the political environment, and develop a shared vision for the future. ${ }^{27}$ One month later, the congregations formalized their unification by signing the Declaration of Interdependence.

We, the undersigned, hereby commit ourselves to create a powerful organization of the people who will pursue policies which achieve greater metropolitan equity. [...] MOSES, acting in concert with their allies [...] do solemnly publish and declare that all peoples and municipalities of this entire metropolitan area are, and of right ought to be, INTERDEPENDENT ENTITIES. ${ }^{28}$

The unification was simultaneously an organizational and a political move, symbolic of both what they wanted to become and the changes they hoped to bring to the region.

\section{EXPANSION AND CONSOLIDATION}

The decision to unify and expand required a shift in structure. With the founding of MOSES, the districts created an Executive Committee comprised of six elected 
representatives from each district. ${ }^{29}$ Each district maintained responsibility for local recruitment and action with its members. The goal of organizers was to continue to build the base through in-reach campaigns and localized actions, while also recruiting new congregations. With the help of an outside consultant, the organization further restructured to address these goals. ${ }^{30}$ In February 1999, the Executive Committee voted to rename and redefine itself as the Executive Board, as the day-to-day governance body. ${ }^{31}$ It established a series of standing committees to parallel and include membership from district standing committees. ${ }^{32}$ The MOSES Board of Directors redefined its role to function as the ultimate voice of the membership through an annual convention. ${ }^{33}$

For MOSES, the importance of expanding regionally grew in tandem with leaders' interest in regional issues such as mass transit and land use. Whereas congregation- and district-level actions were based on teams within congregations, task forces drew participants to issues relevant across districts. The issue of transit became paramount to key leaders, convinced that a regionally coordinated system is necessary for Detroit's revival. At a public meeting in November 1999, seeking increased state funding for public transit, MOSES brought together 800 church members, as well as county executives, suburban mayors, state legislators, and representatives of five major corporations. Kovari, the lead organizer on transit, explained, "Our strategy is to try to get these players on the same stage and try to create regional unity around increased funding, [ ... ] with people from all of our churches in the background daring them to say no" (Bagwell 1999). The following April, the group organized a hearing on transit funding in the state legislature; their actions led to a $\$ 50$ million increase for public transportation spending (Ankeny 2002).

As MOSES expanded their networks, staff organizers took on more congregations. ${ }^{34}$ In Jeremiah the organizers initially worked with 6-12 core teams. But with expansion the goal grew eventually to manage 25-40 congregations each, to reach 100-150 member institutions total. In the late 1990 s, staff stepped up recruitment to balance city and suburban members. The Executive Director wrote in 1999, "I envision a Fall 2000 entering group of $40+$ suburban congregations ready for a covenant with MOSES congregations." 35

After unification, to better influence state policy, organizer responsibilities expanded to work with not only individual congregations but also task forces and allied organizations in other cities. ${ }^{36}$ In 2000 , one organizer began to work full-time with leaders in Saginaw and Kalamazoo; this statewide initiative became Michigan Interfaith Voice (MIVOICE; Pastor et al. 2009, p. 89). ${ }^{37}$ Another added consulting for Gamaliel in New York and Ohio.

Maintaining congregation-level actions became increasingly difficult. Stretched by their regional responsibilities, professional organizers expected that advanced lay leaders would take on some responsibilities within their churches. The strain surfaced in comments like this: "Director's Summary: I am very disappointed in the lackluster outreach and few actions. [...] Many wait for the organizers to call, plan the action, do the turnout, do the thinking, do the agendas." 38

MOSES continued to build on its successes, but its expansion felt costly to some members who preferred a local focus. In September 1999, the RUTH Board wrote a memorandum to the Executive Committee, listing concerns about the state of the organization, including Gamaliel's training methods, lack of staff time, and the shift to metropolitan organizing. Whereas national organizers emphasized the importance of critical agitation 
to jostle participants from complacency, some trainees felt attacked rather than motivated. ${ }^{39}$ RUTH's letter reported that they had difficulty retaining prospective leaders who attended Gamaliel's national week-long training.

We understand how agitation can provide challenge and direction.... However, we believe these tools should be less confrontational and more Christian ... trainers seem to hold preconceived assumptions that all their trainees are experienced in community organizations. ${ }^{40}$

Led by Rev. Henry Sims, RUTH also argued that the districts were inadequately staffed for the ends they desired, and some RUTH leaders believed Gamaliel held too much influence over Detroit organizing priorities, "e.g., Urban Sprawl is a Gamaliel issue not a grassroots issue." RUTH leaders also feared an undermined role for the districts: "The continuation of our current approach will leave little reason for District involvement... and culminate in MOSES being a hollow shell without credibility or respect." 41

This internal discussion carried racial connotations. Implicitly, longstanding racial inequality influenced RUTH's concerns that the needs of city, African American churches would go unmet and the focus would move to suburban and out-state efforts. ${ }^{42}$ Staff organizers opposed RUTH's proposals, worried they would void the Declaration of Interdependence and jeopardize funding based on the metro-equity agenda. The Director wrote,

The rage deep in our souls at conditions and suffering in Detroit and poorer suburbs must be met by hope in new strategies. Old strategies of organizing will not work anymore - they are too limited, insular, and don't take into account changes in our society that have driven people further and further apart geographically, spiritually, racially, economically. ${ }^{43}$

The staff pointed to district and regional achievements as evidence that MOSES could do both and insisted that Gamaliel did not control their territory. ${ }^{44}$ Organizers acknowledged "the complicated path and the hard decisions that have to be made in "metropolitan organizing." 45 Their prevailing belief was that democratic organizations need to change and grow to be relevant: "Every organization has to stretch beyond its own boundaries, be they geographical, issue, or racial." ${ }^{46}$ Gamaliel's Director Greg Galuzzo summed up their thinking, "A congregation-based organization is either growing or dying." 47 MOSES moved forward with its regional agenda.

In 2002, organizers worked with suburban mayors and managers to help establish the Michigan Suburbs Alliance, which supports intergovernmental cooperation and reinvestment in older suburbs. ${ }^{48}$ The MOSES public meeting in September 2002 reached a zenith, convening 5,000 participants. Gubernatorial candidate Jennifer Granholm committed to three pieces of the MOSES transportation agenda: funding public transit with 10 percent of state gas tax revenue; appointing a new Director of MDOT $^{49}$ with a record of support for public transit, and supporting creation of the first regional transportation authority for Detroit. ${ }^{50}$ With the success of this meeting, organizers proclaimed, "MOSES is now on the radar screen nationally." ${ }^{1}$ By 2003 MOSES was active in three counties and about 70 congregations. 
MOSES leaders also added the courts to their action repertoire. In 2003, they brought suit against SEMCOG, to challenge the disproportionate representation of newer suburban governments on SEMCOG's executive committee. A fairer representation of the city's population could redirect more federal transportation dollars to older infrastructure (Schneider 2004). ${ }^{52}$ MOSES lost the case but won political recognition: transit meetings with Detroit's previously unresponsive mayoral staff and over 20 meetings with business leaders and elected officials to find supporters of regional transit (Williams 2006). ${ }^{53}$ Their efforts successfully pressured SEMCOG to study the feasibility of high-speed rail along the I-94 corridor, from Detroit to Metro-Airport and Ann Arbor. MOSES then assisted a group of wheelchair riders to file suit against the City to fix bus wheelchair lifts, instigating investigation of the city by the U.S. DOT. ${ }^{54}$ In October 2005, the city agreed to all demands and settled the case. ${ }^{55}$ In the process, MOSES also helped win passage of a new state mandate requiring all public bus operators to verify working wheelchair lifts.

Despite this increased visibility, in Spring 2004, member evaluations revealed uncertainty about the state of the organization. ${ }^{56}$ By all outward accounts, the 2004 public meeting was a success, bringing in 4,500 participants, including Mayor Kilpatrick and then-Governor Granholm. But participation fell short of the target of 7,000.

The organization's challenges reflected changes in demographic context and the organizing strategy. Gamaliel's organizing model relies on religious institutions and, in particular, a mix of Catholic and Protestant congregations. Since the late 1960s, the Catholic Archdiocese of Detroit closed and clustered dozens of older churches and transferred priests to newer parishes (Alcser 2005; Brand-Williams 2010). In 2003 and 2004, six MOSES pastors were transferred to different churches. These clergy had mobilized 1,000 people in 2002 but could only turn out 200 in 2004 from their new congregations. With the important exception of Detroit's Latinos, the Catholic Church in Detroit no longer has a significant urban base. And mobilization was not only a concern among Catholics; some Protestant member churches moved or closed as well, or continued the long-term adaptation to attract and maintain suburban congregants (Ammerman and Farnsley 1997). The most successful megachurches have become cities unto themselves, offering myriad social services and even job opportunities (Vann 2005). For these clergy, membership in a MOSES is incidental; their size and resources allow direct access to politicians, and service-provision takes priority over mobilization.

Issue expansion also affected mobilization capacity. As MOSES staff became more involved in task forces and interfacing with government officials, there was less attention to "building the base" of core teams. ${ }^{57}$ One organizer explained,

It's been a huge challenge for us to maintain our base. That's why we have to constantly recruit, which we haven't been doing the last couple of years, and we have to constantly rebuild those relationships and build new ones. And the more into issues we get, the less we do the relationship building. (Kovari 2004)

Typically before a public meeting, MOSES would hold congregation in-reach meetings. Victoria Kovari reflected, "We'll go do one-on-ones with people, we'll get people to do one-on-ones with their folks, and we'll end up in a public meeting. But we didn't do that this year, we barely did it two years ago. I think it showed with the weaker base."

Lay leaders shared similar concerns in interviews. Henrietta Rogers, a leader from Greater Southern Baptist, described a change in member participation after MOSES 
became a regional organization. "I can't get them to go to the meetings now like I did when it was with WDIFCO, because it's not of their self-interest. When you start taking on regional things, it's not" (Rogers 2006). Asked if her church members were more concerned with issues like abandoned housing in the neighborhood, she replied, "Instead of abandoned houses all over the state, [laughs] you see what I'm saying?"

After unification, the districts had maintained separate boards until the number of meetings became unwieldy. At a leadership assembly in 2006, leaders approved a change in by-laws that confirmed the dissolution of the districts. The minutes explained, "Since the districts have not been meeting or functioning well for the last several years it is cumbersome even to hold district elections." ${ }^{58}$ But that meant the kinds of issues more likely to arise in district meetings did not have a setting for incubation, especially if a church's core team was inactive. Some members that were a part of the districts in the mid-1990s continued to carry on their own local actions, as did newer members that never had a district affiliation. But others participated in name only, with little involvement in decision making or building the organization.

Angela Kaiser's (2010) recent research on social capital in MOSES confirms a limited use of one-on-ones and limited development of teams within congregations (p. 199). Her interviews reveal, "many congregations did not have organized core teams... . Relationships that were formed and sustained seem to be more a result of individual members reaching out and establishing contact," than an intentional strategy for developing relationships (pp. 246-247). And interviewees report a decline in member participation over time, particularly regarding individual church actions (p. 217).

Kaiser suggests a need for more purposeful bridging strategy to increase understanding and shared identity across race and place. In my interviews, active participants praised the organization for creating bridging opportunities enabling some close, lasting friendships. But the experience of key leaders is distinct from the rank and file in congregations who are often only distantly connected to teams, task forces, and issues. In her surveys, Kaiser finds ongoing city-suburb tensions within the organization and a tendency for certain issue task forces to be racially and geographically homogeneous (p. 233). ${ }^{59}$ The underlying organizing method appears to assume that focusing on issue actions requires enough interaction and respect across identity groups to provide widespread support for the regional agenda. Yet as the organization focuses on developing ties across a larger territory, interracial and intercultural tensions persist. The value of more personal interracial and interreligious exchange may be taken for granted as leaders are pressed to focus on relationships that lead more quickly to desired political outcomes.

\section{ANALYSIS}

The history of MOSES reveals several transitions of scaling up for greater impact, summarized in Figure 2. The top row lists key characteristics that shifted with the move to a citywide and regional structure, including the organization's purpose, relational base, approach to leadership, and strategy for empowerment.

Initially, the work of organizers focused on cultivating relationships within church core teams and across churches to form districts. But the young organizations quickly found that structural forces limited their impact. Leaders were motivated to adopt a regional equity agenda to influence elected officials throughout the region and the state. With 


\begin{tabular}{|c|c|c|c|c|c|c|}
\hline $\begin{array}{c}\text { Organization } \\
\text { characteristics }\end{array}$ & Structure & $\begin{array}{l}\text { Staff to } \\
\text { member } \\
\text { ratio }\end{array}$ & \multicolumn{1}{|c|}{$\begin{array}{l}\text { Primary } \\
\text { purpose }\end{array}$} & $\begin{array}{l}\text { Relational } \\
\text { base for } \\
\text { action }\end{array}$ & $\begin{array}{c}\text { Approach } \\
\text { to } \\
\text { leadership }\end{array}$ & $\begin{array}{l}\text { Democratic } \\
\text { strategy for } \\
\text { empowerment }\end{array}$ \\
\hline \multirow{4}{*}{ Transitions } & $\begin{array}{l}\text { Geographically- } \\
\text { based districts }\end{array}$ & Higher & $\begin{array}{l}\text { Developing } \\
\text { shared } \\
\text { interests } \\
\text { within and } \\
\text { across } \\
\text { congregations }\end{array}$ & $\begin{array}{l}\text { Core } \\
\text { teams } \\
\text { (bonding) }\end{array}$ & $\begin{array}{l}\text { New, } \\
\text { indigenous } \\
\text { leadership } \\
\text { development }\end{array}$ & $\begin{array}{l}\text { Responsiveness } \\
\text { to localized } \\
\text { group needs } \\
\text { (developing a } \\
\text { shared voice) }\end{array}$ \\
\cline { 2 - 7 } & $\begin{array}{l}\text { Metropolitan } \\
\text { coalition }\end{array}$ & Lower & $\begin{array}{l}\text { Mobilization } \\
\text { of defined } \\
\text { interests } \\
\text { regionally }\end{array}$ & $\begin{array}{l}\text { Task } \\
\text { forces } \\
\text { (bridging) }\end{array}$ & $\begin{array}{l}\text { Experienced } \\
\text { leaders act } \\
\text { on behalf of } \\
\text { the group }\end{array}$ & $\begin{array}{l}\text { Representation } \\
\text { of unity for } \\
\text { power } \\
\text { (being heard in } \\
\text { public arena) }\end{array}$ \\
\hline
\end{tabular}

FIG. 2. Summary of organizational transitions with the shift to the regional strategy.

this move, staff energies were spread over a greater geographic area. The decrease in staff attention and change in issue focus were perceived as costs by some members, especially in struggling city neighborhoods.

With the regional strategy, key leaders that emerged from the early organizing efforts shifted their energies toward mobilizing a broader coalition, including suburban congregations, public officials, unions, and advocacy groups (Thayer 2001, 2003; TRU 2008). Whereas core teams continued with varying levels of engagement, task forces became the primary relational base for political action. ${ }^{60}$ This shift made strategic sense given regional trends, including the "shrinking" of the city and the increasing symptoms of disinvestment in older suburbs. Task forces proved adept at the research and coordination necessary for issue campaigns, bringing in a variety of local experts to meet and discuss strategy. In this way, some task forces began to resemble specialized interest groups but with the active participation of nonprofessionals from congregations who developed expertise through their sustained involvement. The approach to leadership shifted as active participants developed experience, took on more responsibility, and became identifiable to others as key leaders.

Finally, this transformation meant a shift in the underlying democratic strategy for empowerment. There are two primary ways that community organizations can empower their membership. The first is by helping people connect personal obstacles to public injustice, or consciousness raising to develop a shared voice. Second, organizations empower their members by helping them be heard-by prioritizing issues, building strategic relationships, making demands, and holding public officials accountable. These are both necessary components of empowerment in civic life and they are not mutually exclusive, but they do require distinct organizational strategies. The former requires organizations to reflect members' unique experiences and validate their struggles. The latter requires groups to frame issues for a wider public and symbolically represent their members as unified in public debate.

Early actions by core teams and districts were empowering by developing a public voice for a diverse group of congregations. Once they built a shared identity through local actions, leaders became frustrated by the barriers to being heard at the city level: 
dwindling public resources, city-suburb competition, and officials playing the race card. To challenge these barriers more effectively, strategy shifted from building local districts to expansion into a broader, more diverse coalition.

Being heard serves a symbolic purpose beyond power in numbers. For the leadership, MOSES came to represent regional diversity in an otherwise polarized political environment. Active leaders were always aware of the contrast between their personal experiences of working together and the everyday divisions of race and place in Detroit. The leaders self-consciously viewed themselves as modeling constructive interracial collaboration. ${ }^{61}$ The new regional structure was not only a means to an end but a symbol of what they hoped to achieve: a region that works for the majority of its residents by transcending the boundaries of race, religion, and place. But given the organization's breadth and resource limitations, racial integration and shared purpose did not reach far into the pews.

\section{CODA}

Detroit has faced significant challenges since primary fieldwork for this research ended in 2006. But the city's recent struggles largely hold true to the adage that the more the things change, the more they remain the same. The recession of 2008-2009 compounded a decade of job losses in Michigan, which never recovered from the recession of 2001 (Lupo 2008). In autumn 2011, the region's unemployment rate of 14.4 percent remained the highest among the nation's most populous metropolitan areas (Bureau of Labor Statistics 2011). Excesses of the mortgage industry, predatory lending, and job loss undermined Detroit's already-weak housing market, and Detroit's homeowners buckle under the highest property tax rates in the state (Aguilar 2007; MacDonald 2011). If there is anything positive to say about these crises, it is that Detroit's embattled reputation has sparked interest among young people to be a part of a more sustainable renewal. And while the city continues to hemorrhage residents, many Detroiters are committed to reshaping their city. In 2010 the Bing administration launched the "Detroit Works" project, a visioning process for consolidating services and land use in response to perpetual budget deficits. ${ }^{62}$ City-hosted community meetings involved nearly 10,000 Detroiters in vigorous discussions of vacancies and safety, as well as fears that the process will sideline some neighborhoods.

Despite recent crises, the purpose and direction of MOSES has largely remained the same. MOSES is not a service provider and can do little for members undergoing foreclosure or suffering job loss. The organization maintains active task forces on transportation, immigration, and health care, and added a grocery store task force to address the city's "food desert" (Kaiser 2010, p. 187; Walsh 2010). Some leaders argue that MOSES does not receive enough credit for its efforts, such as the encouraging progress toward a regional transit system-a goal MOSES has pursued for over a decade (Helms 2011; Turman 2011). The complexity of their targeted issues, involvement in state and national coalitions, and incremental policy progress enable co-optation of MOSES's agenda and undermines the ability to claim victories (Hardaway 2011).

The organization has faced tremendous leadership turnover in recent years. It lost senior organizers to other opportunities, hired new organizers, and changed presidents twice since 2010 (Kaiser 2010, p. 195; Hardaway 2011). For the Director, this period of 
adjustment raised questions of how to best maintain multiple levels of organizing. In recognition of a need for more in-depth relationship building, MOSES staff recently developed a survey tool for congregations (Hardaway 2011). Lay people will collect personal stories from their peers on specific issues, in contrast to typically open-ended one-to-one interviews. Leaders hope that this information, once compiled, will provide a snapshot for congregations of member concerns while also rebuilding a stronger relational base. If applied across the organization's regional members, this could also be a way for members to compare lived realities to better understand their differences and find shared ground for future action.

\section{CONCLUSIONS}

This paper traces how several small, district-based organizations "scaled up" to unite as a citywide and regional organization, with aspirations to influence state politics. The collective decision to unite and expand was based on recognition of limitations at the local level, both in terms of the influence of urban churches and in terms of the capacity of local government, given a decreasing population and tax base. The decision to unite was also based on the availability of an alternative frame for understanding the origins of neighborhood conditions in regional terms. Local people built an influential organization rooted in religious institutions with multiplying allies across government, academia, and advocacy organizations. They sought to create an organization that mirrored the scope of the problem and expand their base of power. As in other urban areas throughout the United States, they engaged in "metropolitics" (Orfield 1997).

The historical trajectory reveals many successes and challenges of scaling up a community organization. The congregation-based model of organizing seeks to reflect members' current interests and yet grow to build relationships that will transcend existing political boundaries. These are ambitious goals requiring multiple levels of relationships and targets, at times pulling members in different directions. This paper identified three key challenges that, in conclusion, suggest ways to balance multiple, at times competing, organizational goals.

The first challenge of expansion for a democratic organization is maintaining the group's shared identity. In the mid-1990s, the members thoughtfully discussed and sought expansion for greater influence; once members agreed to grow, that choice drew energy away from interpersonal relationships and church-based teams that had connected organizers to the base and grassroot leadership development. The districts shifted from a more parochial focus on local parks and housing abandonment to pressuring legislators for transit funding and involvement in national coalitions. These shifts created new opportunities for active members in leadership and policy expertise but led others to question their collective purpose and shared interests.

MOSES's authenticity is rooted in its congregational base and clergy-driven mobilization. ${ }^{63}$ The priorities of congregation-based organizations must be true to member concerns, the source of their identity, and democratic power. Organization-wide framing should continually reflect and complement local concerns. If internal relationship building still speaks to the needs of member clergy, then it makes sense for organizers to support bonding within congregations and organize around their priority issues. This need not mean a return to parochialism if organizers can also engage members in political 
education on the larger forces shaping local conditions and incorporate interfaith and interracial bridging.

The development of this bridging social capital is a second key challenge for scaling up. In MOSES, both city and suburban members are committed to regional collaboration, but in practice, working relationships across racial groups remain limited (Kaiser 2010, p. 197). In most cases this does not reflect an outright unwillingness to collaborate but different kinds of issues loom largest in members' worldviews. City clergy are focused on issues of immediate urgency: reductions in social welfare programs, the state's emergency manager law, crime, and beleaguered public schools (Turman 2011). Suburban clergy are concerned about foreclosures and the decline of services but are less accustomed to bringing political issues to the pulpit. Suburban congregants often do not believe they share much in common with Detroiters, and city clergy wonder how their peers north of 8 Mile Road can be committed to a shared agenda if their members are not.

In response, MOSES could address racial and religious differences more directly across congregations and task forces. This would allow rank and file members to address lingering questions about the purpose and control of the organization. Some members have raised concerns that a regional organization will respond to the needs of its most privileged members and reproduce unequal power relations. A more intentional bridging strategy would include not only bringing together diverse members who agree on certain policy objectives but also working through the tensions that arise from shared ownership in an unequal society. As the northern suburbs of Detroit continue to diversify, in part due to continued population loss in the city, there may be more opportunities to raise bridging conversations within and across congregations.

In this spirit of inclusiveness, MOSES could also reach out more to non-Christian institutions. It has few Jewish or Islamic members, not to mention other faiths, despite the increasing international diversity of Southeast Michigan. Such an effort should not be for expansion's sake alone, because superficial bridging without engagement from the base could backfire for an already-stretched organization. Instead, exposure to greater religious diversity could facilitate deeper discussions on the organization's identity and make MOSES a more credible voice of interfaith leadership in the region.

A third challenge for growing local organizations is to clarify relationships with state and national networks. Organizers are pressed to balance multiple responsibilities: recruiting and training local members while analyzing changing political conditions and opportunities for action. The more levels of government a group targets, the more challenged organizers will be to maintain this balance and respond to shifts in the political and issue environment. Here is an opportunity for national networks such as Gamaliel to assist by following higher-level political dynamics and coordinating across local campaigns. In its historical progression, some MOSES members expressed uncertainty over the affiliate's relationship with the national network and concern over the influence of national staff. The introduction of national issues into local agendas can feel like an imposition to some members. For instance, when MOSES joined Gamaliel's campaigns for the Dream Act and immigration reform, some members questioned whether these should be local priorities. The relative isolation of the immigration task force exacerbated this tension because other members had little understanding of the pressures on immigrant communities. Although it is the responsibility of local affiliates to facilitate internal bridging, national staff can help by supporting coordination across affiliates and framing national initiatives around local agendas. 
This case study enabled a close look at the expansion of a particular organizing project in an especially challenging context. The generalizability of the findings is uncertain, in comparison both to groups affiliated with different national networks and to organizations in cities facing different challenges than Detroit. Practitioners would benefit from further research comparing organizations working for metropolitan equity, to identify how scaling up can be most beneficial for member empowerment and policy impact in various political contexts.

These research findings are also limited by the method of data collection. Aside from a focus group of suburban clergy early in the research process, this study more fully represents the views of city clergy than their suburban peers who joined later, although their perspectives were represented in task force and clergy caucus meetings throughout the fieldwork. Given the long-term shifts in population and diversification of out-migrants, further research is needed on the challenges and opportunities for metroequity campaigns in suburban areas. A comparative study could help scholars identify what factors affect the ability of organizations to successfully scale up. Such factors may include the age, experience, and scope of a local organization, the strength of member commitment and social divisions in the base, the religious or congregational underpinning of the organization, or the extent of regional collaboration by local governments. ${ }^{64}$

This study relied heavily on archival data and the memories of interviewees to document discussions and debates from the mid-1990s. For future research, real-time observations could better assess internal power dynamics across racial or socioeconomic groups and characterize the quality of such discussions driving organizational change. Such research would be of interest to the students of democratic practices beyond the niche field of community organizing. For instance, the study of organizing could further our understanding of tradeoffs between democratic practices that privilege elite or populist engagement (Skocpol 2003), and of tradeoffs for organizations investing in deliberation or mobilization (Mutz 2006). Although scholars have closely documented the philosophy and culture of institution-based organizing, there remains much to learn about the process of decision making and reckoning within these organizations. This case reveals concerted efforts at building a diverse membership and developing policy expertise in contrast to traditional understandings of community organizing as single-mindedly populist or conflict-driven. The strategy to scale up in metropolitan Detroit reflected an urgent desire to do it all, to exercise democratic ideals of inclusivity and listening while also building power for greater impact, mindful of the costs of inaction.

\section{Acknowledgments}

This research was made possible by support from the Non-Profit and Public Management Center and the Ford Doctoral Fellowship in Public Policy at the University of Michigan. The author is also grateful to the organizers and leaders of MOSESDetroit. The author specially thanks Angela Kaiser for her suggestions. This paper also benefited from the comments of anonymous reviewers at City $\mathcal{E}^{\circ}$ Community and from participants at the Southern Political Science Association Conference, January 2010. 


\section{Notes}

${ }^{1}$ I draw from the Skoll Foundation's definition of scaling up a program: "to significantly increase its impact in size, amount, or extent." This can occur through "growing an organization's own capacity, developing independent affiliates or franchises, encouraging widespread adoption of the model by others or creating strategic partnerships that enable greater reach" (Skoll 2010).

${ }^{2}$ DeFilippis, Fisher, and Shragge (2010) write that Alinsky "was uncertain how to resolve the tension inherent in building a national organizational structure... while focusing on the specific needs and people involved in each local community" (p. 51).

${ }^{3}$ ACORN has been an important model for what can be accomplished nationally-although it is not an example of institution-based organizing. ACORN's decisions on "where to focus campaigns" were pragmatic choices, based on the context of political opportunities and constraints (Swarts 2007, p. 147).

${ }^{4}$ The Industrial Areas Foundation (IAF) and People Improving Communities Through Organizing (PICO) are two extensive congregation-based organizing networks in the United States (Warren and Wood 2001).

${ }^{5}$ Cited documents are from the MOSES archive at the University of Michigan's Bentley Historical Library (hereafter, Bentley archive).

${ }^{6}$ In 2003, MOSES listed 43 congregations in the city of Detroit as dues paying members; I ultimately interviewed clergy and lay leaders representing 26 of those churches; 14 of were predominantly white congregations in northern suburbs and 3 were in suburbs south of the city. MOSES also had four African American or mixed race congregations in older suburbs bordering the city on the Southwest. The 49 formal interviews included 26 African Americans, 17 white-Anglos, and 6 Latinos. For initial interview questions, see (Rusch 2008, p. 227). Although the questions did not ask about changes in organizational structure, the topic arose in multiple interviews in response to the question of how the interviewee became involved in MOSES. In this way the analysis is also informed by grounded theory methodology (Strauss and Corbin 1994, p. 274).

${ }^{7}$ Exceptions included Rev. Joe Gagnon of Melvindale, whom I interviewed as an early leader of Jeremiah, and Rev. Stan Ulman, who was moved to a suburban parish.

${ }^{8}$ Chrysler's edgy, pro-Detroit Super Bowl ad drew local acclaim and some critique in 2011 (Dzwonkowski 2011; Weinstein 2011).

${ }^{9}$ The designated Metropolitan Planning Organization (MPO), Southeast Michigan Council of Governments (SEMCOG), operates as an advisory body. See http://www.semcog.org/.

${ }^{10}$ For a complete list of WDIFCO members, see Bentley archive, Box 1, CHD National folder. It originally included five Catholic, three Baptist, two Evangelical Lutheran, one Episcopal, and one Presbyterian Church.

11 The name Jeremiah was suggested by Rev. Fenton of Zion Lutheran, based on Jeremiah 32:15, "Houses, fields and vineyards shall again be bought in this land."

${ }^{12}$ Gamaliel is one of a handful of national congregation-based organizing networks that trace their roots to the practices and philosophy of Saul Alinsky and to the Civil Rights and Labor Movements. See http://www.gamaliel.org/.

${ }^{13}$ Gamaliel Foundation, "Church Based Organizing: A Strategy for Ministry," Bentley archive, Box 1, Folder 1, pages I-XIV.

${ }^{14}$ Safe Zones were supported by a partnership with the Detroit Bureau of Substance Abuse. MOSES News Update, Fall 2003. Also see Bentley archive, Box 3, Exec. Board 1998 folder, Exec. Summary (11/14/96), National CHD Application, page A-3.

${ }^{15}$ Bentley archive, Box 3, Executive Board 1998 folder, MOSES Board Minutes, May 15, 1997, p. 2.

${ }^{16}$ That victory was the result of collaboration by leaders from Sts. Andrew and Benedict, All Saints Catholic, Waterfall Baptist, Southwestern Church of God, and Mt. Zion Missionary Baptist Church (Selwa 2002). In addition, Jeremiah created the Jeremiah Community Development Corporation (JCDC) and in 1999, built 60 low-income single family homes through its $\$ 12$ million Newberry Estates project in Southwest Detroit (Ankeny 


\section{CITY \& COMMUNITY}

2002). This was the largest single-family development effort in the area in decades (Chambers 2002). Chaired by Kovari, the JCDC acquired vacant lots and secured $\$ 6$ million in tax credits from the state housing authority (Gargaro 1997).

${ }^{17}$ Bentley archive, Box 3, Executive Board 1998 folder, letter dated Mar. 17, 1995, p. 2.

${ }^{18}$ RUTH stands for Residents United Together in Hope. Explaining the reason for the separation, Liske said there were "some people that were in housing that felt they had to cultivate a favorable relationship with the city. [... ] It was two different ways of operating. And eventually it was spun off” (2005).

${ }^{19}$ Bentley archive, Box 1, CHD National folder, 1995 Application, Section A, Introduction, page 1.

${ }^{20}$ Bentley archive, Box 3, Executive Board 1998 folder, letter dated Mar. 17, 1995, p. 4.

${ }^{21}$ ESTHER stood for East-siders Standing Together (Esparza 1996). Three pastors were initially involved, but apparently all three envisioned themselves as the president and "they weren't exactly talking with each other" (Liske 2006). This sector of the city posed unique challenges for community organizing. Known for areas of concentrated poverty and abandonment, it was sometimes called a "demilitarized zone." In addition, the east side had strong community development organizations in place, with their own processes of training and organizing. These included U-SNAP-BAC (United Streets Networking and Planning: Building a Community) housing and the Warren/Connor Economic Development Corporation (Liske 2006).

${ }^{22}$ Bentley archive, Box 2, Jeremiah Board Meeting 1994-1996 folder, Minutes, Jeremiah Project Board Meeting, February 8, 1996, page 1.

${ }^{23}$ Bentley archive, Box 2, Jeremiah Board Meeting 1994-1996 folder, flier included with Board Meeting Agenda, April 11, 1996.

${ }^{24}$ Bentley archive, Box 2, Jeremiah Board Meeting 1994-1996 folder, Rev. E. Cain. Speech is undated, page 4 .

${ }^{25}$ Kovari later became a senior organizer with MOSES. She formerly organized with the Detroit Tenants' Union and Detroit Organization of Tenants, and worked with the United Community Housing Coalition in the 1980s. In 1993 she managed City Councilor Maryann Mahaffey's campaign for Council President. Mahaffey was a champion for Detroit's affordable housing and homeless organizations and challenged Mayor Young's budget proposals (Shaw 1996).

${ }^{26}$ Bentley archive, Box 1, Video: "Together for a Change."

${ }^{27}$ Bentley archive, Box 2, Blue Binder (1999), MOSES Visioning Conference flier.

${ }^{28}$ Bentley archive, Box 1, Declaration of Interdependence folder.

${ }^{29}$ Bentley archive, Box 1, folder 1, "Expand, Recruit, Consolidate": A draft plan for MOSES 2000-2003 by Bill O'Brien, March 6, 2000, page 6.

${ }^{30}$ Bentley archive, Box 3, Executive Board Meetings 1999-2000 folder, "Dr. Hal Stack's Recommendations for Restructuring," June 17, 1998, pages 1-5. The Executive Committee voted to recommend that the MOSES Board accept the recommendations, February 11, 1999. Memo from the Structure and Governance Task Force, to the MOSES Executive Committee, dated Jan. 4, 1999, pages D1-D7.

${ }^{31}$ Bentley archive, Box 3, Executive Board Meetings 1998 folder, MOSES Bylaws, Amendments approved August 13, 1998, page 1.

${ }^{32}$ Each standing committee was chaired by a member of the MOSES Executive Board and included representatives from the parallel district committees. Examples include Finance and Development, Membership Recruitment and Training, and Fundraising.

33 At this convention the board would elect MOSES officers, review the progress of the organization, and approve the budget.

${ }^{34}$ Bentley archive, Box 3, Executive Board Meetings 1999-2000, "Paradigm Shift: Leadership-Driven Organizing = Leaders Acting Like Organizers."

${ }^{35}$ Bentley archive, Box 3, Executive Board Meetings 1999-2000, "6 month review of MOSES 1999” by Bill O'Brien (submitted to the Executive Board Aug. 19, 1999), page 2. 
${ }^{36}$ Phone conversation with Liske, November 16, 2006.

37 These included ISAAC (Interfaith Strategy for Advocacy and Action in the Community) in Kalamazoo and Ezekiel in Saginaw, which incorporated with MOSES as MI-Voice, September 30, 2003. They were later joined by JONAH (Joint Religious Network for Advocacy and Hope) in Battle Creek, Michigan.

${ }^{38}$ Bentley archive, Box 3, Executive Board Meetings 1999-2000, “6 month review of MOSES 1999” by Bill O'Brien (submitted to the Executive Board Aug. 19, 1999), page 4, under "Core Team Weaknesses."

${ }^{39}$ Bentley archive, Box 3, Executive Board Meetings 1999-2000 folder, Executive Committee Minutes, Oct. 30, 1997, page 3 .

${ }^{40}$ Bentley archive, Box 3, Executive Board Meetings 1999-2000 folder, Letter to Greg Galuzzo and Senior Staff from the RUTH Board, July 13, 1999.

41 The RUTH Executive Board voted in support of the memo. Bentley archive, Box 3, Executive Board Meetings 1999-2000. Memo dated Sept. 2, 1999, page 1.

42 Bentley archive, Box 3, Executive Board Meetings 1999-2000, MOSES Memo from Bill O’Brien to Rev. Barlow, President, Oct. 5, 1999. For a fuller discussion of racial politics in MOSES, see (Rusch 2010).

${ }^{43}$ Bentley archive, Box 3, Executive Board Meetings 1999-2000 folder, Memo from Bill O'Brien to the Executive Board, "RUTH's $3^{\text {rd }}$ Recommendation," page $2 \mathrm{~A}$.

${ }^{44}$ In the end, Rev. Sims left MOSES, with the reason that he was too busy after being elected as the local representative for his denomination. Bentley archive, Box 3, Executive Board Meetings 1999-2000, "Staff Report to MOSES Officers on the RUTH Recommendations," Oct. 9, 1999, pages 1-4.

${ }^{45}$ Bentley archive, Box 3, Executive Board Meetings 1999-2000, MOSES Memo from Bill O’Brien to Rev. Barlow, President, Oct. 5, 1999.

${ }^{46}$ Conversation with Liske, November 16, 2006.

${ }^{47}$ Bentley archive, Box 3, Executive Board 1998 folder, MOSES Board Minutes, May 15, 1997, p. 3.

48 The MSA is now an independent organization encouraging regional collaboration and joint service delivery. See www.michigansuburbsalliance.org.

49 The Michigan Department of Transportation.

${ }^{50}$ Ultimately a court decision prevented the authority's creation, because the deal lacked a funding mechanism (Gray 2006).

${ }^{51}$ Internal report generated 10-10-02 by MOSES staff/board, included in Agenda for PMOC: Public Meeting Organizing Committee Meeting, April 20, 2004, p. 10-11.

${ }^{52}$ Only 5 percent of the SEMCOG executive committee represents Detroit; Detroiters comprise 19 percent of the population of the Council's region (Schneider 2004).

${ }^{53}$ MOSES Program, "Back to Basics," 8th Annual Martin Luther King, Jr. Banquet, January 17, 2005, Major Accomplishments in 2004.

54 This action was led by two MOSES participants, attorneys Richard Bernstein and Gary Benjamin (Schmitt and Schaefer 2005).

55 The Department of Justice agreed to monitor the city's compliance with provisions of the Americans with Disabilities Act. MOSES Program, "In Tribute to Rosa Parks and the 50th Anniversary of the Montgomery Bus Boycott," 9th Annual Martin Luther King Banquet, January 16, 2006, Major Accomplishments in 2005.

56 Organizer Kovari reported on the evaluations. A Catholic leader noted attendance at MOSES meetings was dropping off and questioned how to attain more participation from the congregations. Field notes, April 26, 2004. Public Meeting Organizing Committee meeting agenda.

${ }^{57}$ Conversations with Kovari Dec. 9, 2003, and with Father Joe Gagnon, Jan. 13, 2005.

58 The group decided to elect the Executive Board at-large from the Board of Directors rather than electing representatives from the districts. Leadership Assembly agenda, Feb. 12, 2006. Greater Apostolic Faith Temple, Detroit.

${ }^{59}$ For example, the civil rights and immigration task force and the health care task force. 


\section{CITY \& COMMUNITY}

${ }^{60}$ Kaiser also describes task forces as "the primary vehicle for involvement" of nonclergy in MOSES (p. 232).

${ }^{61}$ For example, the organization promoted itself in terms of this diversity, as "Inter-faith, Inter-racial, Intersuburb, Inter-city." Bentley archive, Box 2, Black Binder, "MOSES In Congress" flier, "Declaration of Interdependence," Oct. 18, 1998.

${ }^{62}$ See the City's website: http://detroitworksproject.com/.

${ }^{63}$ Bentley archive, Box 1, folder 1, "Expand, Recruit, Consolidate: A draft plan for MOSES 2000-2003," March 6, 2000, page 6.

${ }^{64}$ For instance, the PICO network organized at local levels in California for 30 years, including 10 years at the state level, before venturing into national campaigns (Wood 2007, p. 169). In comparison, the districts that created MOSES organized for only about five years before choosing a metro-equity agenda.

\section{REFERENCES}

Aguilar, Louis. 2007. "Wayne Co. Foreclosure Rate Leads the Nation." Detroit News, February 13.

Alcser, George, Michael Chateau, Jesse Cox, Victoria Kovari, John O’Brien, Frank Rashid, and Stanley Ulman. 2005. One Diocese, Many Voices: A Response to the Challenges of Together in Faith. Detroit: Marygrove College.

Amick, Marcus. 1996a. "Jeremiah Project Looks to Expanding its Impact." Michigan Chronicle, May 15-21.

—. 1996b. "NOAH pushes for a stronger police presence." Michigan Chronicle, July 11.

Ammerman, Nancy Tatom, and Arthur Emery Farnsley. 1997. Congregation E Community. New Brunswick: Rutgers University Press.

Ankeny, Robert. 2002. "Head of Public-Transit Coalition Wins Ford Foundation Award." Crain's Detroit Business, September 30.

Askari, Emilia. 1994. "Neighborhoods Stand United: Southwest Detroit, Nearby Cities Vow to Help Rebuild." Detroit Free Press, November 21.

Bagwell, Jennifer. 1999. "Let There be Mass Transit: A Faith-Based Coalition Joins the Fight Against Sprawl." Metrotimes, November 27.

Brand-Williams, Oralandar. 2010. "More Catholic Parishes in Detroit to be Shuttered." Detroit News, December 15 .

Brenner, Neil. 2003. "Metropolitan Institutional Reform and the Rescaling of State Space in Contemporary Western Europe." European Urban and Regional Studies, 10(4): 297-324.

Chambers, Jennifer. 2002. "Faith Group Fights Urban Ills: Inner Ring Suburbs Join Inner-City Group to Develop Solutions." Detroit News, September 15.

Cortes, Ernesto, Jr. 1993. "Reweaving the Fabric: The Iron Rule and the IAF Strategy for Power and Politics." In Interwoven Destinies: Cities and the Nation, edited by H. G. Cisneros (pp. 295-319). New York: Norton.

Darden, Joe T., Richard Child Hill, June Thomas, and Richard Thomas. 1987. Detroit: Race and Uneven Development, Comparative American Cities. Philadelphia: Temple University Press.

DeFilippis, James, Robert Fisher, and Eric Shragge. 2010. Contesting Community: The Limits and Potential of Local Organizing. New Brunswick, NJ: Rutgers University Press.

Delaney, Robert. 1996. "Project Aims to Reclaim Detroit Neighborhoods." Michigan Catholic, January 19.

Dreier, Peter, John H. Mollenkopf, and Todd Swanstrom. 2004. Place Matters: Metropolitics for the Tiventy-First Century, Second Edition. Lawrence, KS: University Press of Kansas.

Dzwonkowski, Ron. 2011. "Did You Feel It? Chrysler Super Bowl Ad Says Detroit's Back." Detroit Free Press, February 7.

Esparza, Santiago. 1996. "Church Groups Join to Wipe Out Blight, Crime." Detroit News, August 14.

Farley, Reynolds, Sheldon Danziger, and Harry J. Holzer. 2000. Detroit Divided. New York: Russell Sage Foundation.

Ganz, Marshall. 2000. "Resources and Resourcefulness: Strategic Capacity in the Unionization of California Agriculture, 1959-1966." The American Journal of Sociology 105: 1003-62.

Gargaro, Paul. 1997. "Tax credit a $\$ 6 \mathrm{M}$ boost to 60 homes in Detroit." Crain's Detroit Business, May 5.

Gillette, Howard. 2005. Camden After the Fall: Decline and Renewal in a Post-Industrial City, Politics and Culture in Modern America. Philadelphia: University of Pennsylvania Press.

Gray, Kathleen. 2006. "Region's Transit, Growth on Agenda." Detroit Free Press, June 2.

Hardaway, Ponsella. 2006. Personal Interview. February 8.

—. 2011. Personal Communication. September 23. 


\section{THE EVOLUTION OF AN ORGANIZING STRATEGY IN DETROIT}

Heathcott, Joseph. 2005. "Urban Activism in a Downsizing World." City Eீ Community 4: 27794.

Helms, Matt. 2011. "Woodward Light Rail Project gets \$2 Million Federal Grant for Study on Birmingham Extension." Detroit Free Press, October 13.

Hopkins, Francis. 1994. "Visger Face-Lift is under Way." Detroit News, December 6.

Kaiser, Angela A. 2010. "Bridging Social Capital Formation in a Faith-Based Organization." Dissertation, Social Work. Wayne State University, Detroit, MI.

Katz, Bruce. 2010. "Obama’s Metro Presidency." City E Community 9:23-31.

Kleidman, Robert. 2004. "Community Organizing and Regionalism.” City E Community 3:403-421.

Kovari, Victoria. 2004. Personal Interview. October 20.

Liske, Cheryl. 2005. Personal Interview. September 28. 2006. Telephone Conversation. November 16.

Ludtke, Doris. 1994. "United, They Fight Back: Jeremiah Project has Clout to do the Job." News-Herald, September 25 .

Lupo, Lee. 2008. "Michigan Lost 315,200 Manufacturing Jobs in 8 years, Report Says." Muskegon Chronicle, September 28.

MacDonald, Christine. 2011. "Owners Escape Tax Debt by Rebuying Foreclosed Homes." Detroit News, September 7.

Miles, Matthew B., and A. Michael Huberman. 1994. Qualitative Data Analysis: An Expanded Sourcebook. Thousand Oaks, CA: Sage.

Miller, Lisa Lynn. 2008. The Perils of Federalism : Race, Poverty, and the Politics of Crime Control. Oxford; New York: Oxford University Press.

Mutz, Diana. 2006. Hearing the Other Side: Deliberative Versus Participatory Democracy. Cambridge: Cambridge University Press.

O’Brien, Bill. 2006. Personal Interview. May 29.

Orfield, Myron. 1997. Metropolitics: A Regional Agenda for Community and Stability. Washington, DC: Brookings Institution Press; Lincoln Institute of Land Policy.

Orfield, Myron, and Thomas Luce. 2003. Michigan Metropatterns. Minneapolis: Ameregis.

Orr, Marion, and Gerry Stoker. 1994. "Urban Regimes and Leadership in Detroit." Urban Affairs Quarterly $30(1): 48-73$.

Pastor, Manuel, Jr., Chris Benner, and Martha Matsuoka. 2009. This Could be the Start of Something Big: How Social Movements for Regional Equity are Reshaping Metropolitan America. Ithaca: Cornell University Press.

Putnam, Robert D. 2000. Bowling Alone: The Collapse and Revival of American Community. New York: Simon \& Schuster.

- 2007. "E Pluribus Unum: Diversity and Community in the Twenty-first Century." Scandinavian Political Studies 30:137-74.

Rogers, Henrietta. 2006. Personal Interview. June 26.

Rogers, Mary Beth. 1990. Cold Anger: A Story of Faith and Power Politics. Denton, TX: University of North Texas Press.

Rusch, Lara. 2010. "Rethinking Bridging: Risk and Trust in Multiracial Community Organizing." Urban Affairs Review 45 (March): 483-506.

Rusch, Lara C. 2008. "Accountability Through Diversity: Challenges for Congregation-Based Community Organizing in Detroit.” Dissertation, Political Science. University of Michigan, Ann Arbor, MI.

Rusk, David. 1993. Cities without Suburbs, Woodrow Wilson Center Special Studies. Washington, DC: Woodrow Wilson Center Press; Distributed by the Johns Hopkins University Press.

—. 1999. Inside Game/Outside Game: Winning Strategies for Saving Urban America. Washington, DC: Brookings Institution.

Santow, Mark. 2007. "Running in Place: Saul Alinsky, Race, and Community Organizing." In Transforming the City: Community Organizing and the Challenge of Political Change, edited by M. Orr (pp. 28-55). Lawrence, KS: University Press of Kansas.

Schattschneider, E.E. 1975. Semisovereign People: A Realist's View of Democracy in America. New York: Dryden Press.

Schmitt, Ben, and Jim Schaefer. 2005. "Mayor on Defensive about Bus Wheelchair Lifts: Settlement Talks between Residents, City Break Down.” Detroit Free Press, March 1.

Schneider, Keith. 2004. "Ferndale, Veteran Activists Say SEMCOG is Undemocratic: Agency's 'UnderRepresentation' of Core Communities Worsens Sprawl.” Great Lakes Bulletin Service, August 28. 


\section{CITY \& COMMUNITY}

Schramm, W. 1971. "Notes on Case Studies of Instructional Media Projects." Working paper. Washington, DC: The Academy for Educational Development.

Scully, Paul. 2008. Opportunity and Equity in a Global Society: A Case for a Unified Approach. New Brunswick, NJ: Rutgers, Edward J. Boustein School of Planning and Public Policy.

Selwa, Robert. 2002. "MOSES: Faith in Action in Metro Detroit." Macomb Daily, September 28.

Shaw, Todd Cameron. 1996. “... Responsible for their Deeds": Political Accountability and Black, Low-Income Housing Advocacy in Detroit, 1933-1993. Dissertation, Political Science, University of Michigan, Ann Arbor, MI.

Skocpol, Theda. 2003. Diminished Democracy: From Membership to Management in American Civic Life. Norman: University of Oklahoma Press.

Skoll. 2010. Skoll Awards: Glossary. Accessed May 7. Available online: http://www.skollfoundation. org/about/skoll-awards/skoll-award-for-social-entrepreneurship-glossary/.

Smock, Kristina. 2004. Democracy in Action: Community Organizing and Urban Change. New York: Columbia University Press.

Statistics, U.S. Bureau of Labor. 2011. Economic News Release: Metropolitan Area Employment and Unemployment Summary. Washington, DC: U.S. Department of Labor. Accessed February 1, 2012: http://www.bls.gov/news.release/metro.nr0.htm.

Stone, Clarence N. 1989. Regime Politics: Governing Atlanta, 1946-1988. Lawrence: University Press of Kansas.

Strauss, Anselm, and Juliet Corbin. 1994. "Grounded Theory Methodology." In Handbook of Qualitative Research, edited by N.K. Denzin and Y.S. Lincoln. Thousand Oaks, CA: Sage.

Sugrue, Thomas J. 1996. The Origins of the Urban Crisis: Race and Inequality in Postwar Detroit, Princeton Studies in American Politics. Princeton, NJ: Princeton University Press.

Swarts, Heidi. 2007. "Political Opportunity, Venue Shopping, and Strategic Innovation: ACORN's National Organizing." In Transforming the City: Community Organizing and the Challenge of Political Change, edited by M. Orr. Lawrence: University Press of Kansas.

Swarts, Heidi J. 2008. Organizing Urban America: Secular and Faith-Based Progressive Movements. Minneapolis: University of Minnesota Press.

Thayer, Kelly. 2001. "Road to Rail: Getting Michigan on Board with Transit Alternatives." Metrotimes, February 21.

- 2003. On the Bumpy Road to Lansing, Again: Citizens Attend Hearing to Oppose Lawmakers' Transportation Policies. Michigan Land Use Institute. Accessed May 19. Available online: http://www.mlui.org/ growthmanagement/full.asp?fileid $=16492$.

Thomas, June Manning. 1997. Redevelopment and Race: Planning a Finer City in Postwar Detroit. Baltimore, MD: Johns Hopkins University Press.

TRU. 2008. Happy Holidays from Transportation Riders United. Accessed May 19. Available online: http:/ / www.detroittransit.org/cms.php?pageid $=57$.

Turman, Rev. Kevin. 2011. Personal Communication. October 13.

Vann, Rev. Edgar. 2005. Personal Interview. November 10.

Vatcher, Cheryl. 1997. "WDIFCO Meeting Draws Big Crowd." Press E Guide, October 30.

Walsh, Dustin. 2010. "MOSES' Vision: Group Pushes to Get a Full-Service Grocery Store with in the City." Crain's Detroit Business, August 22.

Warren, Mark R. 2001. Dry Bones Rattling : Community Building to Revitalize American Democracy, Princeton Studies in American Politics. Princeton, NJ: Princeton University Press.

Warren, Mark R., and Richard L. Wood. 2001. Faith-Based Community Organizing: The State of the Field. Jericho, NY: Interfaith Funders.

Weinstein, Adam. 2011. "Chrysler's Deplorable "Detroit" Super Bowl Ad." Mother Jones, February 7.

Wilson, William J. 1999. The Bridge Over the Racial Divide: Rising Inequality and Coalition Politics. Berkeley: University of California Press.

Wood, Richard L. 2007. "Higher Power: Strategic Capacity for State and National Organizing." In Transforming the City: Community Organizing and the Challenge of Political Change, edited by M. Orr. Lawrence: University Press of Kansas.

Yin, Robert K. 1994. Case Study Research: Design and Methods. 2nd ed. Thousand Oaks, CA: Sage. 


\section{APPENDIX A. LIST OF ABBREVIATIONS}

$\begin{array}{ll}\text { CBCO } & \text { Congregation-Based Community Organizing } \\ \text { CCHD } & \text { Catholic Campaign for Human Development } \\ \text { DOT } & \text { Department of Transportation } \\ \text { ESTHER } & \text { East-Siders Standing Together } \\ \text { HUD } & \text { U.S. Department of Housing and Urban Development } \\ \text { IAF } & \text { Industrial Areas Foundation } \\ \text { ISAAC } & \text { Interfaith Strategy for Advocacy and Action in the Community } \\ \text { JONAH } & \text { Joint Religious Network for Advocacy and Hope } \\ \text { MI-VOICE } & \text { Michigan Interfaith Voice } \\ \quad \text { MOS } & \text { Metropolitan Organizing Strategy } \\ \text { MOSES } & \text { Metropolitan Organizing Strategy Enabling Strength } \\ \text { MPO } & \text { Metropolitan Planning Organization } \\ \text { NOAH } & \text { Northeast Organization Allied for Hope } \\ \text { PICO } & \text { People Improving Communities Through Organizing } \\ \text { RUTH } & \text { Residents United Together in Hope } \\ \text { SEMCOG } & \text { Southeast Michigan Council of Governments } \\ \text { U-SNAP-BAC } & \text { United Streets Networking and Planning: Building a Community } \\ \text { WDIFCO } & \text { West Detroit Interfaith Community Organization }\end{array}$

\section{Crecimiento Regional: La evolución de una estrategia de activismo social en Detroit (Lara Rusch)}

\section{Resumen}

En contextos marcados por una desigualdad metropolitana insoluble y recursos locales limitados, los activistas comunitarios a menudo se sienten obligados a dirigir sus acciones a niveles de gobierno más allá de la autoridad local. Este artículo presenta un caso de este tipo en Detroit, con proyectos locales de activismo en los que se usó esta estrategia de crecimiento ("scaling up") a mediados de los años '90 con el fin de desarrollar una agenda regional de equidad. Usando observación participante, archivos y entrevistas, el artículo examina este proceso de unificación e identifica cambios cruciales con respecto al propósito, la plataforma de relaciones, el enfoque sobre el liderazgo y la estrategia de empoderamiento. Aunque el proceso de crecimiento ayudó a los miembros a llevar a cabo acciones más sofisticadas e influenciar niveles superiores de gobierno, también implicó un gran desafío para la organización a la hora de mantener su membresía. Esta investigación sugiere que el proceso de "scaling up" implica soluciones de compromiso para las organizaciones de base al tener que responder a su membresía original y, a la vez, construir una estructura representativa al nivel regional, capaz de superar divisiones en el ambiente político. 